\title{
ESSAYS
}

\section{Recuperating First Amendment Doctrine}

\author{
Robert Post*
}

Contemporary First Amendment jurisprudence seeks to protect the abstract fact of communication. In this essay, Professor Post argues that this ambition has led to deep doctrinal incoherence. He illustrates this incoherence by examining two specific areas of First Amendment law- the question of what triggers First Amendment scrutiny, and the issue of time, place, and manner regulations. The essay asserts that the doctrinal disarray in these two areas of First Amendment law stems from the fact that the Court has attempted to locate constitutional value in speech itself. But, Professor Post contends, the constitutional values actually recognized by First Amendment jurisprudence inhere instead in discrete social practices. Professor Post argues that First Amend-. ment doctrine will continue to flounder until the Court establishes a new framework for First Amendment jurisprudence, one in which particular forms of social structure form the basic units of analysis rather than speech as such.

We as it were turned on a knob which looked as if it could be used to turn on some part of the machine, but it was a mere ornament, not connected with the mechanism at all.

Ludwig Wittgenstein ${ }^{1}$

Constitutional law inhabits the tension between doctrine and decision. Courts must decide cases correctly, but they must also explain their decisions in the language of doctrine. Doctrine guides the judgments of lower courts, the actions of government officials, and the conduct of citizens generally. In recent years something seems to have gone seriously amiss with the Supreme Court's ability doctrinally to elucidate its First Amendment decisions. In fact its First Amendment doctrine has begun to display an insouciance so pronounced as to mark a virtual divide between the language of doctrine and the resolution of cases.

Although the pattern of the Court's recent First Amendment decisions may well be (roughly) defensible, contemporary First Amendment doctrine is never-

* Alexander F. \& May T. Morrison Professor of Law, School of Law (Boalt Hall), University of California at Berkeley. I would like to thank Steve Barnett, Jesse Choper, Robert Cole, Meir DanCohen, Daniel Farber, Paul Mishkin, Steven H. Shiffrin, Rodney Smolla, and Jan Vetter for their helpful comments. This paper was first presented at a symposium entitled Freedom of Speech at the End of the Century sponsored by the Department of Justice of the Government of Catalonia.

1. Ludwi Wittgenstein, Philosophical Innovations $\S 271$ (G.E.M. Anscombe trans. 1958). 
theless striking chiefly for its superficiality, its internal incoherence, its distressing failure to facilitate constructive judicial engagement with significant contemporary social issues connected with freedom of speech. Oliver Wendell Holmes once remarked how difficult it was to "think accurately-and think things not words." 2 Our First Amendment jurisprudence has become increasingly a doctrine of words merely, not of things.

Systematically to demonstrate this, of course, would require a treatise. But I am confident that any close student of the area would agree with my assessment. To give a specific and concrete sense of the depths into which our First Amendment doctrine has fallen, I shall in the next two sections of this essay examine two distinct fields of First Amendment jurisprudence: the threshold question of what should trigger First Amendment scrutiny, and "time, place, and manner" regulations. I highlight these doctrinal areas because they shall later prove convenient for illustrating my larger theme. The reader, however, could undoubtedly choose her own favorite First Amendment doctrine to dissect; with few notable exceptions, the game has unfortunately become all too easy.

In the third section of this essay, I address how we have come to this sorry pass. The suggestion I shall propose is that the Court has been working within a paradigm of free speech that has systematically caused it to formulate doctrine in confused and fruitless ways. The Court has imagined that the purpose of First Amendment jurisprudence is to protect speech as such. But in fact the constitutional values advanced to justify this protection inhere not in speech as such, but rather in particular social practices. My hypothesis is that First Amendment doctrine will continue to flounder until it focuses clearly on the nature and constitutional significance of such practices.

\section{The Problem with the Spence Test: What Should Trigger First AMENDMENT SCRUTINY?}

The First Amendment protects "the freedom of speech, or of the press."3 Like any legal provision, the Amendment must contain threshold conditions that specify when its particular doctrines and values will be activated and applied. This question is quite distinct from the merits of a specific controversy. A court can uphold government regulations on the ground that they need not be evaluated according to First Amendment standards, or it can uphold the same regulations on the quite different ground that, having applied First Amendment standards, the regulations are valid and withstand constitutional scrutiny. In order to determine which path of analysis a court should pursue, we must have boundary criteria for deciding when First Amendment standards shall be brought into play.

2. Letter from Oliver Wendell Holmes to Harold J. Laski (May 9, 1925), in 1 Hormes-LASKI LETTERS 738 (Mark DeWolfe Howe ed., 1953).

3. U.S. Const. amend. I. 
To the extent that contemporary First Amendment doctrine has self-consciously addressed these criteria, ${ }^{4}$ it has been through the case of Spence $v$. Washington, in which the Supreme Court was asked to determine whether the First Amendment protected a defendant charged with "improper use" of the American flag. 5 The defendant, a college student outraged by the American invasion of Cambodia and the killings at Kent State University, had hung an American flag upside down outside his apartment and had affixed on the flag with removable black tape a "peace symbol." He was convicted of violating a Washington state criminal law that prohibited the exhibition of a United States flag on which had been "placed any . . . figure, mark, picture, design, [or] drawing." 6

The Court began its analysis by asking whether the case implicated the First Amendment. It did so by inquiring whether the defendant's

activity was sufficiently imbued with elements of communication to fall within the scope of the First and Fourteenth Amendments, for as the Court noted in United States v. O'Brien ..., "[w]e cannot accept the view that an apparently limitless variety of conduct can be labeled 'speech' whenever the person engaging in the conduct intends thereby to express an idea."

The Court in Spence thus framed the threshold issue of whether the specific standards of the First Amendment should be applied in terms of an inquiry into the nature of the activity restricted by state statute. The Court stated that First Amendment scrutiny would be triggered whenever "an intent to convey a particularized message was present, and in the surrounding circumstances the likelihood was great that the message would be understood by those who viewed it." "These criteria (known as the Spence test) have been used ever since by lower courts to guide their decisions about whether to apply First Amendment protection. ${ }^{9}$ The Supreme Court has itself used the test as recently as 1989 in Texas v. Johnson. ${ }^{10}$ In that case the Court, pondering the conviction of a defendant charged with desecrating a flag, summarized the test in this way:

We must first determine whether Johnson's burning of the flag constituted expressive conduct, permitting him to invoke the First Amendment in challenging his conviction.

In deciding whether particular conduct possesses sufficient communicative elements to bring the First Amendment into play, we have asked whether "[a]n

4. Susan H. Williams, Content Discrimination and the Fìrst Amendment, 139 U. PA. L. Rev. 615, 646 n.132 (1991).

5. 418 U.S. 405 (1974).

6. WASH. Rev. CODE ANN. $\$ 9.86 .020$ (West 1988), quoted in Spence, 418 U.S. at 407. (1968)).

7. Spence, 418 U.S. at 409 (citation omitted) (quoting United States v. O'Brien, 391 U.S. 367,376

8. Id. at $410-11$.

9. E.g., United States v. Hayward, 6 F.3d 1241, 1249-50 (7th Cir. 1993); Steirer v. Bethlehem Area Sch. Dist., 987 F.2d 989, 995-97 (3d Cir. 1993); Young v. New York City Transit Auth., 903 F.2d 146, 153-54 (2d Cir.), cert. denied, 498 U.S. 984 (1990); Parate v. Isibor, 868 F.2d 821, 827-28 (6th Cir. 1989); United States v. McDermott, 822 F. Supp. 582, 588 (N.D. Iowa 1993); Naturist Soc'y, Inc. v. Fillyaw, 736 F. Supp. 1103, 1111 (S.D. Fla. 1990).

10. 491 U.S. 397 (1989). 
intent to convey a particularized message was present and [whether] the likelihood was great that the message would be understood by those who viewed it."11

The Spence test thus appears to have enjoyed the normal life of a relatively minor First Amendment doctrine. What is curious, however, is that the doctrine is transparently and manifestly false. The test cannot plausibly be said to express a sufficient condition for bringing "the First Amendment into play."

A small but telling example plainly demonstrates the problem with the Spence test. Consider laws imposing criminal sanctions for the defacement of public property. Such laws do not "bring the First Amendment into play"; a defendant accused of defacing a city bus would not have a First Amendment defense. This would be true regardless of whether the defacement took the form of random blotches of color spray-painted onto the walls, or the form of words like "Down with Clinton" or "Eric is Cool" carved into the seats. Although in the latter case the defendant has satisfied the Spence test-his words carry a particularized message that is likely to be understood by his audience-no court in the country would consider the case as raising a First Amendment question.

This example can be multiplied indefinitely, for any action can at any time be made communicative in a manner that satisfies the Spence test. Think of the racist who commits a violent crime successfully to communicate a message of racial prejudice and hate. ${ }^{12}$ In such a case we do not say that the state's interest in prohibiting violence outweighs the defendant's interest in communication, but rather that the First Amendment does not come into the case at all. If the Spence test were to describe actual judicial practice, we would expect criminals routinely to attempt to immunize their crimes by endowing them with particular messages.

The fundamental difficulty with the Spence test is that it locates the essence of constitutionally protected speech exclusively in an abstract triadic relationship among a speaker's intent, a specific message, and an audience's potential reception of that message. The examples we have been considering, however, suggest that the constitutional recognition of communication as possibly protected speech also depends heavily on the social context within which this triadic relationship is situated. The threshold conditions for applying the First Amendment must thus attend to this social context. An example of how this might be accomplished may be found in the Supreme Court's decisions wrestling with the issue of whether the cinema ought to be protected by the First Amendment.

In the Court's first assay at this problem in 1915, it concluded that motion pictures were not "organs of public opinion"; they were instead "mere representations of events, of ideas and sentiments published and known," not unlike "the multitudinous shows which are advertised on the bill-boards of our cities

11. Id. at 403-04 (1989) (citations omitted) (quoting Spence, 418 U.S. at 410-11).

12. See, e.g., Wisconsin v. Mitchell, 113 S. Ct. 2194, 2199 (1993). 
and towns."13 Thirty-seven years later the Court changed its mind, holding that "it cannot be doubted that motion pictures are a significant medium for the communication of ideas."14

In neither decision did the Court inquire into the communicative status of "particular conduct." It did not, as would have been required by the Spence test, ask whether a specific movie intended to convey a particularized message and whether "the likelihood was great that the message would be understood by those who viewed it." Instead the Court focused on the cinema as a genre or "medium," which is to say as a set of social conventions and practices shared by speakers and audience. The Court asked whether these conventions and practices deserved constitutional protection. It assumed that if a medium were constitutionally protected by the First Amendment, each instance of the medium would also be protected; ${ }^{15}$ courts need not and perhaps should not ask whether any particular film succeeded in communicating its specific message. ${ }^{16}$

So, for example, if Andy Warhol had made his famous movie Sleep by simply filming the poet John Giorno asleep for six continuous hours, ${ }^{17}$ and if the question of the movie's First Amendment status were to arise, no sane court would approach the question by asking whether Sleep intended to convey a particular message that was likely to be understood. Instead the court would recognize Sleep as part of the genre of the cinema and entitled to First Amendment status for that reason alone.

This suggests an important but largely underappreciated point: The "ideas" prized by First Amendment jurisprudence are often as much a product of First Amendment media as they are independent "entities" transparently conveyed by such media. The point can be most plainly seen in the example of Marcel Duchamp's readymade sculpture, The Fountain, which he submitted to the Exhibition of Independent Painters in New York in 1917.18 The Fountain was

13. Mutual Film Corp. v. Industrial Comm., 236 U.S. 230, 243-45 (1915); see John Wertheimer, Mutual Film Reviewed: The Movies, Censorship, and Free Speech in Progressive America, 37 AM. J. LEGAL HIST. 158 (1993).

14. Joseph Burstyn, Inc. v. Wilson, 343 U.S. 495, 501 (1952).

15. See, e.g., Iota Xi Chapter of Sigma Chi Fraternity v. George Mason Univ., 993 F.2d 386, 38991 (4th Cir. 1993) (holding fraternity's "ugly woman" contest protected because "inherently expressive" in form even if of little or no quality).

16. In its recent opinion in Hurley v. Irish-American Gay, Lesbian and Bisexual Group, 63 U.S.L.W. 4625,4629 (U.S. June 19, 1995), the Court apparently recognized for the first time this tension between a focus on media for the communication of ideas and Spence's focus on the communication of particular messages. The Court held that "parades" were themselves "mediums of expression," and it concluded that for this reason parades need not communicate specific messages in order to qualify for First Amendment protection. The Court explicitly stated that "a narrow, succinctly articulable message is not a condition of constitutional protection, which, if confined to expressions conveying a 'particularized message,' cf. Spence v. Washington ... would never reach the unquestionably shielded painting of Jackson, music of Arnold Schönberg, or Jabberwocky verse of Lewis Carroll." Id.

17. This is not actually how Warhol made Sleep. In fact Warhol filmed Giomo over a period of several weeks and edited down the result. PATRICK S. SMTTH, ANDY WARHOL's ART AND FIMMS 155 (1986). The movie was thus far from a perfectly transparent reproduction of a physical event.

18. George Hugnet, The Dada Spirit in Painting. 7, 9 CAHIERS D'ART 1932, 1934, reprinted in The Dada Panters ANd PoEts: AN ANTHolocy, at 123, 139 (Robert Motherwell ed. \& Ralph Manheim trans., 1951); see also Gabrielle Buffet-Picabia, TRANSITION, Apr.-May 1938, reprinted in The Dada Painters and Poets: An Anthology, at 13, 14 (Robert Motherwell ed. \& Maria Jolas trans., 1951). 
notoriously nothing other than a men's urinal, signed by Duchamp with the name R. Mutt. But what had previously been merely a urinal was transformed by the force of its incorporation into the acknowledged medium of an art exhibition into "a sheer signifier, a 'word that says nothing but that it is a word,' ... an 'intepretant' filled with all the historical meanings of the field of conditions in which the fact of its existence resonates."19 This transformation is made possible because artists and spectators share conventions that establish the medium of art exhibitions, and these conventions can by themselves generate forms of human interaction that are acknowledged as "ideas" within the jurisprudence of the First Amendment. Thus while legal regulation of a urinal in a men's bathroom would not bring the First Amendment into play, regulation of exactly the same urinal in an art exhibition would. The difference lies entirely in the existence of social conventions that create constitutionally meaningful relationships.

We should note, however, that the facilitation of communication is not by itself a sufficient reason for social conventions to be valued by the First Amendment. Navigation charts for airplanes, for instance, are clearly media in which speakers successfully communicate particularized messages. And yet when inaccurate charts cause accidents, courts do not conceptualize suits against the charts' authors as raising First Amendment questions. ${ }^{20}$ They instead regard the charts as "'products' for the purpose of products liability law."21

This suggests that social conventions, to serve the values protected by the First Amendment, must do more than merely facilitate the communication of particularized messages. They must at a minimum also presuppose and embody a certain kind of relationship between speaker and audience. We might roughly describe that relationship as dialogic and independent. Both Sleep and The Fountain assume that their audiences will autonomously query their meaning and authority. Navigation charts do not receive First Amendment protection, however, because we interpret them as speaking monologically to their audience, as inviting their audience to assume a position of dependence and to rely on them. The primary legal value in such a situation is to protect the

19. Thierry de Duve, Pictorial Nominalism: On Marcel Duchamp's Passage from PantING TO THE ReAdYMade 186 (Dana Polan \& Thierry de Duve trans., 1991). de Duve writes:

It was up to posterity to say if the urinal belonged to culture; [Duchamp] himself could not care less. But he reserved for himself the naked symbolic function, the speech act that would name art. The name mattered to him, the pact that would unite the spectators of the future around some object, an object that added nothing to the constructed environment and did not improve on it but, quite the contrary, pulled away from it, bearing no other function than that of a pure signifier, the pact itself.

Id. at 115.

20. See, e.g., Brocklesby v. United States, 767 F.2d 1288, 1294-95 (9th Cir. 1985), cert. denied sub nom. Jeppesen \& Co. v. Brocklesby, 474 U.S. 1101 (1986); Saloomey v. Jeppesen \& Co., 707 F.2d 671, 676-77 (2d Cir. 1983); Aetna Casualty \& Sur. Co. v. Jeppesen \& Co., 642 F.2d 339, 342-43 (9th Cir. 1981); cf. Winter v. G.P. Putnam's Sons, 938 F.2d 1033, 1035-36 (9th Cir. 1991) (distinguishing physical products such as aeronautical charts from "how to use" books).

21. Winter, 938 F.2d at 1035. 
integrity of that reliance, which is to say to impose objective standards of liability.

To summarize the argument so far: First Amendment analysis is relevant only when the values served by the First Amendment are implicated. These values do not attach to abstract acts of communication as such, but rather to the social contexts that envelop and give constitutional significance to acts of communication. The doctrinal category of "media for the communication of ideas" is a useful way to focus attention on these social contexts; it is a legal conclusion that organizes protection of the constitutional values that we perceive in particular kinds of social contexts. The Spence test fails because it ignores social context; it does not state a sufficient condition for bringing the First Amendment into play because social contexts can sometimes render individual acts of communication into events without First Amendment value.

The Spence test also fails because it does not articulate a necessary condition for bringing the First Amendment into play. Spence frames the threshold condition for triggering First Amendment scrutiny far too narrowly by focusing exclusively on the nature of the conduct that is regulated. In fact our First Amendment jurisprudence is concerned not merely with what is regulated, but also with why the state seeks to impose regulations. According to established First Amendment standards, laws enacted to serve improper interests are unconstitutional for that reason. This principle is independent from the scope of a regulation's application, so the Court will use the First Amendment to strike down a statute it finds to have been enacted for inappropriate purposes even if the statute does not apply to recognized media for the communication of ideas. "Where the government prohibits conduct precisely because of its communicative attributes," writes Justice Scalia in Barnes v. Glen Theatre, Inc., "we hold the regulation unconstitutional." 22

Texas $v$. Johnson is a good example of such a decision. In that case the defendant was convicted for burning an American flag in violation of a Texas flag-desecration statute. The statute defined desecration as defacing, damaging or physically mistreating the flag "in a way that the actor knows will seriously offend one or more persons likely to observe or discover his action."23 The Court reversed the conviction because it interpreted the statute as serving the interest of suppressing messages antagonistic to the values of national unity and nationhood, and it viewed this purpose as prohibited by the First Amendment. Faced with a statute that did not apply to a recognized medium for the communication of ideas, the Court stated: "It is, in short, not simply the verbal or nonverbal nature of the expression, but the governmental interest at stake, that helps to determine whether a restriction on that expression is valid." 24

There are thus two independent kinds of considerations that have in fact triggered First Amendment scrutiny. The first involves the question of what is

22. 501 U.S. 560,577 (1991) (Scalia, J., concurring) (emphasis omitted).

23. Tex. Penal Code Ann. $§ 42.09$ (1989) (repealed 1990) (quoted in Texas v. Johnson, 491 U.S. 397, 400 n.l (1989)).

24. 491 U.S. at 406-07. 
being regulated, and it turns on the issue of whether the regulation at issue seeks to restrict a recognized medium for the communication of ideas. The second involves the question of why the state seeks to regulate, and it turns on the nature of the interests which the regulation serves. We can express these two conditions in the form of the following two-by-two table:

\section{TABLE I}

\begin{tabular}{|l|c|c|}
\hline & $\begin{array}{c}\text { Interests } \\
\text { Triggering F.A. } \\
\text { Doctrine }\end{array}$ & $\begin{array}{c}\text { Interests Not } \\
\text { Triggering F.A. } \\
\text { Doctrine }\end{array}$ \\
\hline $\begin{array}{l}\text { Medium For } \\
\text { Communication of Ideas }\end{array}$ & 1 & 2 \\
\hline $\begin{array}{l}\text { Non-Medium For } \\
\text { Communication of Ideas }\end{array}$ & 3 & 4 \\
\hline
\end{tabular}

Table I offers a convenient way of summarizing important threshold conditions for the application of First Amendment scrutiny. Cases in cell 1 unproblematically involve the First Amendment and include some of the most important decisions in the First Amendment canon, like New York Times $v$. Sullivan ${ }^{25}$ and Brandenburg $v$. Ohio. ${ }^{26}$ Cases in cell 2 are typically those in which the state plausibly asserts a neutral and legitimate state interest, like preventing litter or raising revenue, and in which the state regulates constitutionally recognized media for the communication of ideas in the name of that interest. Such cases also bring the First Amendment into play; examples include Schneider v. State ${ }^{27}$ and Minneapolis Star \& Tribune Co. v. Minnesota Commissioner of Revenue. ${ }^{28}$

Cases in cell 3 also implicate First Amendment concerns; they typically involve what the Court has come to call "symbolic conduct." Although a great deal of ink has been spilled on the question of whether such symbolic conduct is or is not "speech" for purposes of the First Amendment, a close analysis of these cases indicates that they almost invariably turn on judicial scrutiny of the purposes served by the regulation at issue. Illustrative is the Court's decision in R.A.V. v. City of St. Paul, ${ }^{29}$ which examined a statute that the Court concluded was "based on hostility ... towards the underlying message expressed" by a particular form of behavior. ${ }^{30}$ The Court vacated the defendant's conviction even though the statute in the case was applied only to "fighting words" that were concededly without independent First Amendment protection. Finally, cases in cell 4 ought not to trigger First Amendment analysis at all, even if they

25. 376 U.S. 254 (1964) (establishing the actual malice standard for libel actions).

26. 395 U.S. 444 (1969) (prohibiting criminal punishment of speech advocating violence or lawbreaking unless actually intended and likely to produce violence or law-breaking).

27. 308 U.S. 147 (1939) (holding that the state may not pursue a legitimate interest in reducing litter by means of a ban on all leafletting on public streets).

28. 460 U.S. 575 (1983) (holding that state may not impose differential tax burden on the press).

29. 112 S. Ct. 2538 (1992).

30. Id. at 2545 . 
involve individual acts of a communicative nature. Expressive acts of property defacement would fall within this cell.

We might get a firmer sense of the different meanings of these cells by comparing various kinds of prosecutions of, let us say, antiwar demonstrators. States typically have laws requiring permits for those who conduct parades, and they typically justify such laws by reference to general interests like traffic control. If our antiwar demonstrators were to be prosecuted for failing to obtain a permit under such a law, the case would fall in cell 2: It would involve the regulation of a traditional medium for the communication of ideas in order to serve a neutral and legitimate state interest.

Notice that this use of the concept of a "medium for the communication of ideas" obviates the temptation to fall back upon the old distinction between "speech in its pristine form" and "expression mixed with particular conduct,"31 between what Harry Kalven used to call "speech pure" and "speech plus."32 This distinction has sometimes confused the Court's First Amendment doctrine, particularly in the context of "patrolling, marching, and picketing." 33 The very concept of a medium presupposes that constitutionally protected expression does not inhere in abstract and disembodied acts of communication of the kind envisioned by Spence, but is instead always conveyed through social and material forms of interaction. ${ }^{34}$

Suppose that some in the antiwar demonstration burned flags, and suppose that they were prosecuted under a flag desecration statute that sought to preserve symbols of national unity and nationhood. Johnson stands for the proposition that such prosecutions would shift to cell 3 , where they would properly command First Amendment attention. But if these same demonstrators were instead prosecuted under a general arson statute, the case would essentially be analogous to that of a terrorist who is prosecuted for a murder that successfully communicated a political message. The prosecutions would be located in cell 4 and fail to trigger First Amendment scrutiny.

We might offer a somewhat more complex account of Table I by noting the existence of a small but significant class of cases in which constitutional characterization of the state's interest varies with the scope of its application. State interests that seem perfectly legitimate when applied to behavior will sometimes be deemed constitutionally suspect when applied to media for the communication of ideas. A good example of this phenomenon is Cohen $v$. California, ${ }^{35}$ in which the defendant was convicted for violating a California statute prohibiting " maliciously and willfully disturb[ing] the peace or quiet of any neighborhood or person ... by . . offensive conduct . . ." "'36

31. Cox v. Louisiana (Cox II), 379 U.S. 559, 564, 566 (1965). $22-23$.

32. Harry Kalven, Jr., The Concept of the Public Forum: Cox v. Louisiana, 1965 Sup. CT. Rev. 1,

33. Cox v. Louisiana (Cox I), 379 U.S. 536, 555 (1965).

34. As Kalven states: "I would suggest that all speech is necessarily 'speech plus.' If it is oral, it is noise and may interrupt someone else; if it is written, it may be litter." Kalven, supra note 32, at 23.

35. 403 U.S. 15 (1971).

36. Id. at 16 (quoting CAL. Penaz CODE $\S 415$ ) (alteration in original). 
The statute at issue in Cohen appeared on its face to be a proper and legitimate regulation of conduct. Applied to a disorderly inebriate roistering on a residential street corner, the case would fit unproblematically into cell 4 of Table I. Yet the defendant in Cohen was convicted for displaying on his jacket the words "Fuck the Draft," and Justice Harlan in his opinion for the Court deemed this circumstance to be crucial:

The conviction quite clearly rests upon the asserted offensiveness of the words Cohen used to convey his message to the public. The only "conduct" which the state sought to punish is the fact of communication. Thus, we deal here with a conviction resting solely upon "speech," ... not upon any separately identifiable conduct which allegedly was intended by Cohen to be perceived by others as expressive of particular views but which, on its face, does not necessarily convey any message and hence arguably could be regulated without effectively repressing Cohen's ability to express himself. ${ }^{37}$

In this passage Harlan commits the Court to constitutionally evaluate the California statute in terms of its distinct and separate application to a specific medium for the communication of ideas-the language of political discourse. Harlan does not in his opinion pursue this evaluation by examining the effect of California's law on this medium, but he instead focuses on the legitimacy of the purposes served by California law when applied to political discourse. What makes this procedure so unusual is that courts do not ordinarily assess the legitimacy of state interests differently when applied to media for the communication of ideas than when applied to conduct in general.

The procedure was justified in Cohen, however, because the purposes advanced by California to support the statute assume an entirely different constitutional complexion when evaluated within the limited context of media for the communication of ideas. At the time of Cohen there was already a rich and textured First Amendment jurisprudence restricting state attempts to regulate media in order to prevent disorder or to expunge offense. California should not have been able to evade this jurisprudence simply by folding these very purposes into a general regulation of conduct, and Harlan's approach was calculated to forestall any such evasion. Harlan's analysis in effect moves the case from cell 4 to cell 1 of Table 1 .

It is rare for state purposes to change their complexion in this way. The interests served by prohibitions on murder or arson do not appear constitutionally different when applied to political demonstrations. Nor do the interests served by labor, antitrust, tax, or environmental regulations when applied to media like newspapers. ${ }^{38}$ Such regulations, even though general in form, can and should be evaluated in terms of their effects on media for the communication of ideas, as would ordinarily be true in cell 2; but such evaluations do not generally involve constitutional recharacterization of the purposes served by the regulations. In contrast, the statute at issue in Cohen appears to serve per-

37. Id. at 18 (emphasis in original) (citation omitted).

38. See, e.g., Minneapolis Star \& Tribune Co. v. Minnesota Comm'r of Revenue, 460 U.S. 575, 581 (1983); Associated Press v. NLRB, 301 U.S. 103, 132-33 (1937). 
fectly proper state interests when applied to general behavior, but not so when applied to media for the communication of ideas.

A contemporary example of a similarly anomalous statute was addressed by the Court in Barnes v. Glen Theater, Inc. ${ }^{39}$ In that case the Court upheld the application of an Indiana statute that "proscribed public nudity across the board" to nude dancing in nightclubs. ${ }^{40}$ The case was five-to-four, with no opinion for the Court. A central theme for at least four of the Justices inclined to uphold the statute was that the law furthered "a substantial interest in protecting order and morality." 41 The four Justices correctly observed that this interest is quite legitimate when applied to behavior generally. Nevertheless, as Cohen itself directly holds, this interest is quite problematic when applied specifically to media for the communication of ideas. ${ }^{42}$

If my analysis is correct, therefore, the outcome in Barnes would have been different if Indiana were to have applied its statute to accepted media for the communication of ideas, as for example by attempting to prohibit nudity in movies or in the theater. Any such prohibition would serve interests deemed highly problematic by fully elaborated principles of First Amendment jurisprudence. ${ }^{43}$ Crucial to the result in Barnes, then, is the distinction between what the Court is prepared to accept as a medium for the communication of ideas, and its implicit understanding of nude dancing in nightclubs, which at least three of the majority Justices explicitly characterized as merely "expressive conduct." 44 Application of the Indiana statute to the cinema in the theater should shift the analysis of the case from cell 4 to cell 1 of Table 1 .

I do not wish to propose Table I as a comprehensive summary of the threshold conditions for the application of First Amendment analysis. In fact, for reasons I will explain later, I believe that Table I should only be used in a limited set of circumstances, in part because the very concept of a medium for the communication of ideas can be defined only by reference to the particular problems of public discourse. Nevertheless Table I indicates that even relatively superficial reflection can take us a great distance from the primitive focus of the Spence test.

Table I reveals, for example, why the Spence test fails to articulate a necessary condition for the application of First Amendment analysis. Evaluation of a state's interests in cell 3 ought not to depend upon whether the actions of a particular defendant are communicative in nature. This point can be illustrated by Buckley v. Valeo, ${ }^{45}$ in which the Court struck down federal restrictions on independent expenditures by candidates during election campaigns. The decision has been criticized for various reasons, but a particularly humiliating line

39. 501 U.S. 560 (1991).

40. Id. at 566 (Rehnquist, C.J., plurality opinion).

41. Id. at 569 (Rehnquist, C.J., plurality opinion); see id. at 575 (Scalia, J., concurring). But see id. at 682 (Souter, J., concurring).

42. 403 U.S. at $22-26$.

43. See, e.g., Erznoznik v. City of Jacksonville, 422 U.S. 205, 208-12 (1975).

44. Barnes, 501 U.S. at 566 (Rehnquist, C.J., plurality opinion).

45. 424 U.S. 1 (1976). 
of attack has been that Buckley equated money with speech, a most problematic move. ${ }^{46}$ The thrust of the Court's opinion in Buckley, however, was to locate the case in cell 3 of Table I, and therefore to focus on the justifications advanced by Congress for its campaign finance regulations. The Court, concentrating on "the interests served by the Act," based its decision on a careful assessment of the Act's ambition of "equalizing the relative ability of all voters to affect electoral outcomes by placing a ceiling on expenditures for political expression by citizens and groups." 47 Constitutional analysis of this ambition can comfortably proceed whether or not specific campaign expenditures are a medium for the communication of ideas. It can even proceed whether or not specific campaign expenditures intend to convey particularized messages that are likely to be understood by an audience. Buckley thus illustrates why Spence fails to state even a necessary condition for bringing the First Amendment into play.

\section{The Problem with the Clark Test: Time, Place, and Manner REGULATIONS}

If the Spence test concerns a question that does not often arise and has not received much development and attention, the doctrine I discuss in this section is among the most important and most frequently invoked contemporary First Amendment tests. I am referring to the concept of "time, place, and manner" regulations. ${ }^{48}$

The Supreme Court first introduced the concept of "time, place and manner" regulations into First Amendment jurisprudence in 1940,49 and the phrase assumed doctrinal status the next year in Cox v. New Hampshire. ${ }^{50}$ In Cox the Court upheld a state statute requiring that those wishing to parade on public streets first obtain a license. The Court interpreted the statute as authorizing regulations only "of time, place and manner so as to conserve the public convenience," 51 by which it meant roughly that the statute imposed on licensing authorities a ministerial duty to issue parade licenses, subject only to the necessity of accommodating competing legitimate public interests in the use of public streets. In effect the Court held that in the face of multiple valid claims upon the use of the streets, some effort must be made to satisfice the various inconsistent demands. (1976).

46. E.g., J. Skelly Wright, Politics and the Constitution: Is Money Speech?, 85 YALE L.J. 1001

47. Buckley, 424 U.S. at 17.

48. A similar phrase appears in the Constitution: "The Times, Places and Manner of holding Elections for Senators and Representatives, shall be prescribed in each State by the Legislature thereof; but the Congress may at any time by Law make or alter such Regulations, except as to the Places of chusing Senators." U.S. CONST. art. I, § 4, cl. 1.

49. Cantwell v. Connecticut, 310 U.S. 296, 304 (1940). A variant of the phrase occurs in Lovell v. City of Griffin, 303 U.S. 444, 451 (1938) (invalidating a city ordinance that banned all pamphleting "at any time, at any place, and in any manner" without a city permit).

50. 312 U.S. $569,575(1941)$.

51. Id. at $575-76$. 
The Court termed regulations that had this coordinating function "time, place and manner" regulations. It sharply distinguished such regulations from state laws that did not seek to coordinate speech interests with competing valid claims, but that sought instead to subordinate speech interests to competing valid claims. So, for example, in Schneider v. State the Court struck down a city ordinance that banned leafletting in order to serve the legitimate interest of preventing trash and litter. 52 Even though the city ordinance was content-neutral and was justified by reference to a valid state purpose, the Court did not view it as a time, place, and manner regulation, but as a flat-out restriction on speech.

By the 1970s, however, the Court had lost sight of this important distinction between coordination and subordination. In 1976, in Buckley v. Valeo, the Court asserted that its precedents stood "for the proposition that the government may adopt reasonable time, place, and manner regulations, which do not discriminate among speakers or ideas, in order to further an important governmental interest unrelated to the restriction of communication." 53 Buckley detached the concept of time, place and manner regulations from the particular circumstances of Cox, in which the concept had implicitly served to coordinate competing valid claims upon a single resource. Buckley transformed time, place, and manner regulations into restrictions on speech that could be imposed anywhere, so long as the restrictions met certain criteria. Restrictions could meet these criteria and nevertheless subordinate speech to valid competing government interests.

Thus transformed, the concept of time, place, and manner regulations received black-letter status in 1984 in Clark v. Community for Creative NonViolence, in which the Court announced that "time, place, or manner" restrictions

are valid provided that they are justified without reference to the content of the regulated speech, that they are narrowly tailored to serve a significant governmental interest, and that they leave open ample alternative channels for communication of the information. 54

The Court has since repeatedly held that any state restrictions on speech that can satisfy this tripartite test are constitutionally valid time, place, and manner regulations. The result, in my judgment, has been an unmitigated disaster.

\section{A. Criteria [2] and [3]}

Table I is helpful in demonstrating the depth of this disaster. Clark proposes three criteria for a valid time, place, and manner regulation. The first of these criteria is that restrictions on speech must be

52. 308 U.S. 147 (1939).

53. Buckley, 424 U.S. I at 18. Grayned v. City of Rockford, 408 U.S. 104, 116 (1972), was an important precedent in this process of generalization. For a roughly contemporaneous usage, see Virginia State Board of Pharmacy v. Virginia Citizens Consumer Council, Inc., 425 U.S. 748, 771 (1976). For a good discussion of the development of the test, see Williams, supra note 4, at 638-644.

54. 468 U.S. 288, 293 (1984). 
[1] justified without reference to the content of the regulated speech . . . .55

This criterion divides regulations which serve purposes that trigger First Amendment concerns from those which do not. It thus distinguishes cases that fall into the right-hand column of Table I from cases that fall into the left-hand column. If we confine our attention to regulations that pass the first criterion, we are dealing with cases that belong to the right-hand column, which is to say to cells 2 and 4 of Table I.

The Clark test requires that to be constitutional these regulations must pass two additional criteria, which demand that they be

[2] narrowly tailored to serve a significant governmental interest, and [3] that they leave open ample alternative channels for communication of the information. 56

Table I strongly suggests that First Amendment jurisprudence ought to deem unproblematic regulations which fall into cell 4 , and that it ought to focus attention on the impact on the relevant medium for the communication of ideas of regulations which fall into cell 2. Before its recent redefinition of time, place, and manner doctrine, the Court traditionally engaged in just such assessments with regard to regulations in cell 2.57 Criteria [2] and [3] of the Clark test, however, do not distinguish regulations that fall into cell 4 from those that fall into cell 2. They instead pose two general and undifferentiated queries, queries the Court has made plain are to be understood as neither rigorous nor critical.

The Court has held that criterion [2] requires merely that "the means chosen" by a particular regulation "are not substantially broader than necessary to achieve the government's interest," and that in reaching this judgment courts are to "defer" to the government's determination that its interests are in fact "best served by" the regulation it has chosen to enact.58 And the Court has made plain the limited significance of criterion [3] in Renton v. Playtime Theatres, Inc., 59 in which it assessed the validity of zoning regulations imposed on adult motion picture theaters. ${ }^{60}$ Although the Court of Appeals had found that the zoning regulations forced the theaters into 520 acres of land in which there were "no 'commercially viable' adult theater sites,"61 the Supreme Court found criterion [3] satisfied because "the First Amendment requires only that Renton refrain from effectively denying respondents a reasonable opportunity to open and operate an adult theater within the city, and the ordinance before us easily meets this requirement."62 The "ample alternative channels of communication" guaranteed by criterion [3], in other words, need be neither actual nor

55. Id.

56. $I d$. (1939).

57. See, e.g., Konigsberg v. State Bar, 366 U.S. 36 (1961); Schneider v. State, 308 U.S. 147

58. Ward v. Rock Against Racism, 491 U.S. 781, 800 (1989).

59. 475 U.S. 41 (1986).

60. The Court assumed that the movies shown by these theaters were not obscene and hence were protected by the First Amendment. Id. at 44.

61. Id. at 53.

62. Id. at 54. 
demonstrable; they can be entirely theoretical and putative. ${ }^{63}$ Seen from a sufficiently detached perspective, of course, "alternative" channels of communication will always exist.

The Court has confirmed that criteria [2] and [3] are to be read as extraordinarily lenient, because it has frequently reiterated that the Clark test is to be understood as equivalent to the standards put forth in United States $v$. $O^{\prime}$ Brien $^{64}$ for the regulation of symbolic conduct. ${ }^{65}$ In $O^{\prime} B r i e n$, which involved the prosecution of a defendant for burning his draft card to protest the Vietnam War, the Court announced that the regulation of expressive conduct is constitutional if the regulation

is within the constitutional power of the Government; if it furthers an important or substantial governmental interest; if the governmental interest is unrelated to the suppression of free expression; and if the incidental restriction on alleged First Amendment freedoms is no greater than is essential to the furtherance of that interest. 66

The $O^{\prime} B r i e n$ test is and was meant to be extremely permissive. ${ }^{67}$ The only portion of the test that has bite is the inquiry into whether the governmental interest at stake "is unrelated to the suppression of free expression." This inquiry, like criterion [1] of the Clark test, essentially distinguishes between the two columns of Table I. But because the O'Brien test was specifically designed to address restrictions on symbolic conduct rather than on media for the communication of ideas, regulations deemed by $O$ 'Brien to be "unrelated to the suppression of free expression" will necessarily fall into cell 4 . We have already noted that regulations in cell 4 ought not to trigger First Amendment scrutiny, and the $O^{\prime} B r i e n$ test has traditionally functioned to approve such regulations with a minimum of constitutional fuss. ${ }^{68}$

This has important implications for the interpretation of the Clark test. Consider cases that involve regulations which the O'Brien test would classify as furthering a governmental interest that "is unrelated to the suppression of free expression" and which the Clark test would classify as "justified without reference to the content of the regulated speech." Such cases will fall into the right hand column of Table $I$, in either cell 2 or cell 4 . The Court's equation of the Clark and $O^{\prime} B r i e n$ tests means that we ought to reach the same outcome in

63. It should be noted that the Court in Renton even rephrased criterion [3] to require only the existence of "reasonable alternative avenues of communication." Id. at 53.

64. 391 U.S. 367 (1968).

65. "[W] have held that the $O^{\prime}$ Brien test 'in the last analysis is little, if any, different from the standard applied to time, place, or manner restrictions.' " Ward v. Rock Against Racism, 491 U.S. 781, 798 (1989) (quoting Clark v. Community for Creative Non-Violence, 468 U.S. 288, 298 (1984)). See Turner Broadcasting Sys., Inc. v. F.C.C., 114 S. Ct. 2445, 2469 (1994); Barnes v. Glen Theatre, Inc., 501 U.S. 560, 566 (1991) (Rehnquist, C.J.).

66. 391 U.S. at 377.

67. For a good discussion of the $O^{\prime}$ Brien test, see John Hart Ely, Flag Desecration: $A$ Case Study in the Roles of Categorization and Balancing in First Amendment Analysis, 88 HARv. L. REv. 1482 (1975); see also Keith Werhan, The O'Briening of Free Speech Methodology, 19 ARIz. ST. L.J. 635, 640-41 (1987); Williams, supra note 4, at 647. For a recent indication that the Court may be willing in some contexts to read the $O^{\prime} B$ rien test more strictly, see Turner, 114 S.Ct. at 2469-72.

68. Werhan, supra note 67 , at 643 . 
our constitutional evaluation of these cases, no matter which test we use. But the $O^{\prime}$ Brien test assesses such cases as though they all fell into cell 4 of Table I, and this implies that criteria [2] and [3] of the Clark test should be interpreted in the same way.

In essence, therefore, the Court has fashioned a doctrine that refuses to acknowledge any constitutional distinction between regulations in cell 2 and regulations in cell 4. The Court's revised version of time, place, and manner regulations holds that there is no difference between restrictions of an acknowledged medium for the communication of ideas and restrictions of a non-medium, so long as the interests served by such restrictions do not themselves trigger First Amendment analysis.

Such doctrine is obviously obtuse and unacceptable. Its literal application would imply that a law prohibiting newspapers in order to save forests would receive lenient scrutiny, equivalent to that proposed by $O^{\prime} B r i e n$ for the assessment of the regulation of symbolic conduct. Of course no court if actually faced with such a law would view it as constitutionally unproblematic, whatever its eventual decision on the merits. This gulf between doctrinal articulation and the practices of actual judgment is a sure sign that the Court's doctrine has developed thoughtlessly, untethered to the purposes that it is actually serving.

The bankruptcy of this doctrine recently became plain in City of Ladue $v$. Gilleo, ${ }^{69}$ in which the Court assessed the constitutionality of an ordinance that sought to serve concededly legitimate aesthetic interests by banning all residential signs. ${ }^{70}$ The case is a classic illustration of cell 2 of Table I, because it concerns an ordinance with a neutral and appropriate justification that completely prohibits "an important and distinct medium of expression."71 The ordinance should easily have passed constitutional muster according to the Court's own previously reiterated interpretations of the Clark test, yet in Ladue the Court struck the ordinance down because it would "prohibit too much protected speech."72 Although technically basing its decision on the grounds that the ordinance did not " 'leave open ample alternative channels for communication," "73 in fact the Court, as Justice O'Connor recognized in her concurring opinion, returned to its traditional method of using a "balancing" test to assess the impact of the ordinance on the affected medium. ${ }^{74}$ The essential point is that this perfectly appropriate and commonsense response to the Ladue regulations required the Court to twist and evade its own recent doctrinal pronouncements. Far from assisting in the resolution of the case, that doctrine proved a positive impediment.

69. 114 S. Ct. 2038 (1994).

70. The ordinance excepted "residence identification" signs, "for sale" signs, and signs warning of safety hazards. Id. at 2040.

71. Id. at 2045.

72. Id. at $2043,2045-46$.

73. Id. at 2046 (quoting Clark, 468 U.S. at 293).

74. Id. at 2048 (O'Connor, J., concurring). 


\section{B. Criterion [1]}

The three criteria of the Clark test are each independent and necessary conditions that government restrictions must satisfy before passing constitutional scrutiny as legitimate time, place, and manner regulations. Because criteria [2] and [3] have been interpreted so leniently, the Court has placed increasing pressure on criterion [1], which assesses whether a regulation is "justified without reference to the content of the regulated speech." In fact the Court has used criterion [1] to address the significantly broader question of whether a regulation is "content-neutral," as distinguished from "content-based." The Court has used this distinction to construct what is basically a 2-track system for First Amendment doctrine. Regulations that are content-based are said to receive "the most exacting scrutiny,"75 whereas content-neutral regulations are supposed to receive relatively lax review.

The topic of content neutrality is a large and difficult one. There has been a great deal of academic writing on the subject; indeed this area of First Amendment doctrine is exceptional precisely because it can plausibly be said to have been academically inspired. In this essay I shall explore only one small corner of the issue, the Court's doctrinal development of criterion [1] of the Clark test. ${ }^{76}$ My point will be relatively simple: Whatever the ultimate merits of a First Amendment focus on content neutrality, the Court's doctrinal elaboration of criterion [1] has been haphazard, internally incoherent, and for these reasons inconsistent with any possible principled concern for content neutrality.

In determining whether a regulation is "justified without reference to the content of the regulated speech," the Court has, roughly speaking, created two distinct kinds of doctrinal inquiry. The first, secondary effects doctrine, derives from specifically First Amendment concerns; the second, anti-discrimination doctrine, stems ultimately from forms of analysis most particularly associated with the Equal Protection Clause.

\section{Secondary effects doctrine.}

The First Amendment line of analysis attempts to determine whether the harm a regulation seeks to avert is traceable to the content of the speech that the regulation seeks to proscribe. It does so by asking whether the harm is attributable to the communicative aspects of the speech. If the harm is not so attributable, the regulation is said to be "aimed not at the content" of the speech, but rather at its "secondary effects," 77 and the regulation is deemed content-neutral. But if, on the other hand, the harm is attributable to the communicative content of the speech, then the regulation is said to be addressed to a " 'primary' ef-

75. Turner Broadcasting Sys., Inc. v. F.C.C., 114 S. Ct. 2445, 2459 (1994).

76. For a recent example of the Court's use of content neutrality as a First Amendment principle in a different context, see Simon \& Schuster, Inc. v. New York Crime Victims Board, 502 U.S. 105 (1991) (declaring unconstitutional a "Son of Sam" law which required proceeds from books about a crime to be held in victims' account).

77. City of Renton v. Playtime Theatres, Inc., 475 U.S. 41, 47 (1986) (emphasis added). The phrase "secondary effects" was first used by the Court in Young v. American Mini Theatres, 427 U.S. 50, 71 n.34 (1976) (Stevens, J., plurality opinion). 
fect"78 or "direct impact"79 of the speech, and the regulation is said to be content-based.

The value of this line of analysis depends upon how clearly and usefully the communicative impact of speech is conceptualized in the distinction between primary and secondary effects. There is a consensus that important First Amendment issues are raised if a regulation seeks to prohibit speech because harms will occur if the audience of the speech is persuaded to act in certain ways, ${ }^{80}$ or if the information conveyed by the speech might tend to impel an audience to "act upon it," 81 or if the speech causes "emotive" harms due to its outrageous or offensive character. ${ }^{82}$

But the Court has gone far beyond this core consensus. It has, for example, held that "[1]isteners' reaction to speech is not a content-neutral basis for regulation."83 Although this focus on "listeners' reaction" could be a powerful and far-reaching principle, it is not at all clear what it means. We might use as a benchmark for distinguishing among different possible concepts of 'listeners' reaction" a test once proposed by John Hart Ely to determine whether "the evil the state is seeking to avert is one that is independent of the message being regulated."84 Analyzing restrictions on the use of sound trucks, Ely asked whether the justification for such restrictions would stand even if sound trucks emitted only meaningless static. ${ }^{85}$ Because restrictions on sound trucks seek to ensure the tranquility of residential neighborhoods, and because that tranquility would be impaired by the broadcast of sufficiently loud white noise, Ely concluded that such restrictions should be understood as content-neutral. Quite apart from the question of whether Ely's test is constitutionally justifiable, it is a useful metric for assessing the Court's contemporary doctrine because the test is both clear and internally consistent.

On a superficial reading, the Court's contemporary doctrine appears far broader than Ely's test. The justification for restricting sound trucks is that they keep people awake, which is to say that, in at least a commonsense meaning of the phrase, the justification turns on "listeners' reaction." If the Court intends to accept this broad meaning of the phrase and to interpret criterion [1] to imply that sound truck regulation ought to be classified as content-based, then it has indeed forged an extraordinarily potent weapon for the protection of speech, perhaps more potent than most would find acceptable. But in fact this interpretation of the doctrine is both implausible and inconsistent with the Court's own decisions, which have tended to reflect a view that is far narrower than Ely's test.

78. Linmark Assoc., Inc. v. Township of Willingboro, 431 U.S. 85,94 (1977).

79. Boos v. Barry, 485 U.S. 312,321 (1988) (O'Connor, J., plurality opinion).

80. This insight, of course, is at the root of the application of the Brandenburg test to the advocacy of illegal conduct. Brandenburg v. Ohio, 395 U.S. 444, 448 (1969).

81. Linmark Assoc., 431 U.S. at 94 (1977).

82. R.A.V. v. City of St. Paul, 112 S. Ct. 2538, 2549 (1992) (quoting Boos, 485 U.S. at 321 (plurality opinion of $O^{\prime}$ Connor, J.)).

83. Forsyth County v. Nationalist Movement, 112 S. Ct 2395, 2403 (1992).

84. Jomn Hart Ely, Democracy and Distrust: A Theory of Judicial Review 111 (1980).

85. Id. at 113 . 
The "secondary effects" line of doctrine was established in Renton, which, as we have noted, upheld zoning regulations placed on the location of adult movie theaters. These regulations were "designed to prevent crime, protect the city's retail trade, maintain property values, and generally 'protec[t] and preserv[e] the quality of [the city's] neighborhoods, commercial districts, and the quality of urban life." "86 It is clear that the harms these restrictions sought to avert would not have occurred if the movie theaters in question had simply displayed white screens that conveyed no communicative content whatever. Indeed the restrictions themselves postulated a causal connection between a determinate content-movies with adult themes-and these harms. The Renton ordinance thus fails Ely's test, yet it passes the Court's definition of a law aimed at "secondary effects."

The challenge, then, is to specify the kinds of causal relationships between speech and its impacts that secondary effects doctrine should target. The Court has so far determined that effects caused by speech through persuasion or ideas, through the provision of information, or through the creation of offense, are not secondary. But a host of controversial questions remain. Should a law that prohibits pornographic movies because they allegedly increase the rate of crimes against women be deemed content-based or content-neutral? What of a law that suppresses violence in the media because of an asserted connection to violent crimes? Or a law regulating corporate speech during elections in order to avert voter alienation? Or, to revive an old chestnut, a law banning Communists from key positions in the leadership of national labor unions in order to protect national security? None of these laws would pass Ely's test for content neutrality. But would they pass the requirements of the Court's secondary effects doctrine?

We cannot know, because the Court has so far failed to articulate any substantive First Amendment theory to guide its distinction between primary and secondary effects. The Court has produced only particular judgments, more or less convincing on their own facts. This failure of First Amendment principle not only fundamentally impairs the usefulness of secondary effects doctrine, it also poses serious dangers for freedom of speech. As Justice Brennan has observed in his attack on the doctrine, "secondary effects offer countless excuses for content-based suppression of political speech," and hence the doctrine permits suppression "whenever censors can concoct 'secondary' rationalizations for regulating the content of political speech."87

\section{Antidiscrimination doctrine.}

Secondary effects doctrine is in serious tension with a distinct line of analysis that the Court has also used to elaborate criterion [1] of the Clark test. This line of analysis does not derive from a specifically First Amendment inquiry into the causal consequences of communication, but rather from methods de-

86. 475 U.S. 41,48 (1986) (quoting the challenged ordinance) (alterations in original) (citations omitted).

87. Boos v. Barry, 485 U.S. 312, 335 (1988) (Brennan, J., concurring). 
veloped in the interpretation of the Equal Protection Clause to assess the presence or absence of discrimination. The Court has been drawn to these methods because of its pronounced tendency to conceptualize the goal of content neutrality as a matter of eliminating discrimination "on the basis of the content" of speech. ${ }^{88}$ The issue of discrimination is quite distinct from the issue of the causal efficacy of communication.

Within the domain of the Equal Protection Clause we are accustomed to measuring discrimination according to several distinct dimensions. These include the face of a regulation (whether it draws inappropriate classifications); the justification or purpose of a regulation (whether it serves invidious interests); and the effects of a regulation (whether it has a disparate impact).

In applying criterion [1] the Court has shown little inclination to assess content neutrality in terms of the discriminatory "effects" of a regulation. In Madsen v. Women's Health Center, ${ }^{89}$ for example, the Court recently assessed under criterion [1] a court injunction that strictly regulated protesters at an abortion clinic. Although the injunction had the effect of restricting only the speech of those who opposed abortion, the Court held that "the fact that the injunction covered people with a particular viewpoint does not itself render the injunction content or viewpoint based."90 Instead, said the Court, "[w]e . . . look to the government's purpose as the threshold consideration." 91

The phrasing of criterion [1], which asks whether a regulation is "justified without reference to the content of the regulated speech," seems to fit comfortably with a focus on government purpose. And yet even here the Court's development of the doctrine has been infected with.obscurity. There is a pervasive ambiguity as to whether courts are to assess the justification for a regulation (the reasons that can be adduced for its passage) or the motivation for a regulation (the actual psychological intentions of those who enacted it). These are very different inquiries, and yet the Court has persistently equivocated as to which it means to require.

In Madsen, for example, the Court in an opinion by Chief Justice Rehnquist announced that the discriminatory effect of a regulation "does not in itself demonstrate that some invidious content- or viewpoint-based purpose motivated" its issuance. ${ }^{92}$ Yet in Renton the Court, also in an opinion by Chief Justice Rehnquist, approvingly quoted from $O$ 'Brien to the effect that "[i]t is a familiar principle of constitutional law that this Court will not strike down an otherwise constitutional statute on the basis of an alleged illicit legislative motive."93 The Court's opinions have shifted uneasily between these two different positions. At issue is the important question of whether the Court's test for time, place, and manner regulations is designed to police the processes by which government regulations are actually enacted, or whether it is designed

88. Leathers v. Medlock, 499 U.S. 439, 447 (1991).

89. 114 S. Ct. 2516 (1994).

90. Id. at 2524.

91. Id. at 2523.

92. Id. at 2524 .

93. Renton, 475 U.S. at $47-48$ (quoting United States v. O'Brien, 391 U.S. 367, 382 (1968)). 
instead to police the justifications that can be brought to bear to support these regulations.

Whether criterion [1] is interpreted to scrutinize government justifications or government motivations, it is clear that secondary effects doctrine can not easily be made to fit with a focus on government purpose. ${ }^{94}$ The Court has been so influenced by Equal Protection methodology that it has tended to equate a focus on government purpose with the question of "whether the government has adopted a regulation of speech because of disagreement with the message it conveys." 95 This question is essentially the analogue of the standard Equal Protection inquiry into whether government has enacted a regulation " 'because of,' not merely 'in spite of,' its adverse effects upon an identifiable group." 96 It is basically an inquiry into blame, into whether the purpose of the government has been to violate the law. This inquiry is quite distinct from the objective issues of the causal efficacy of communication that secondary effects doctrine attempts to address.

The project of assessing the blameworthiness of government purposes is afflicted with notorious difficulties. ${ }^{97}$ Courts tend to be skittish of the project because they are reluctant to point fingers of accusation. Problems of evidence and interpretation abound. For these reasons judicial findings of blameworthy government purpose are rare. To equate criterion [1] with the issue of blameworthy.purpose would be to shrink the scope of its application almost to the point of irrelevance.

The Court's use of purpose analysis to interpret criterion [1] as an antidiscrimination measure has thus been shrouded in both ambiguities and difficulties. For this reason some justices have expressed strong opposition to it.98 They have argued that criterion [1] ought to be read instead as a focusing on the "plain statutory language" of a regulation. 99 If a government restriction draws a facial distinction based on the content of speech, then in the view of these Justices it should be regarded as content-based and not as a potentially legitimate time, place, and manner regulation. These justices have contended that such an approach would enable the Court to draw "a bright-line rule" and hence to provide "clear guidance" to governments and individuals. 100

It is clear, however, that interpreting criterion [1] as focusing on the face of a relevant statute would be incompatible with secondary effects doctrine, since it would bypass any independent inquiry into the casual connection between speech and the harm that restrictions on the speech seek to avert. It would also flatly contradict Renton, in which the Court upheld as a legitimate and content-

94. I choose the term "purpose" precisely to equivocate between justification and motivation.

95. Ward v. Rock Against Racism, 491 U.S. 781, 791 (1989).

96. Personnel Adm'r v. Feeney, 442 U.S. 256, 279 (1979).

97. See generally Kenneth Karst, The Costs of Motive-Centered Inquiry, 15 SAN DIEGo L. REv. 1163 (1978).

98. In Boos v. Barry, Justice Brennan, joined by Justice Marshall, argued that a content-based restriction is illegitimate "regardless of the motivation that lies behind it." 485 U.S. 312, 336 (1988) (Brennan, J., concurring).

99. Id. at 336.

100. Id. at $335-36$. 
neutral time, place, and manner regulation an ordinance that on its face singled out for special restrictions movies containing "adult" content. In the teeth of this apparent inconsistency the Court has nevertheless in a recent case read criterion [1] as focusing on the face of a law. In City of Cincinnati v. Discovery Network, Inc., ${ }^{101}$ the Court struck down city regulations that banned newsracks dispensing commercial handbills but not newsracks dispensing traditional newspapers. Applying criterion [1], the Court held that the regulations were content-based because:

\begin{abstract}
Regardless of the mens rea of the city, it has enacted a sweeping ban on the use of newsracks that distribute "commercial handbills," but not "newspapers." Under the city's newsrack policy, whether any particular newsrack falls within the ban is determined by the content of the publication resting inside that newsrack. Thus, by any commonsense understanding of the term, the ban in this case is "content based."102
\end{abstract}

We might safely conclude, then, that not only is secondary effects doctrine inconsistent with the general family of antidiscrimination interpretations of criterion [1], but also that this family contains within itself incompatible readings of criterion [1]. Surveying the doctrine of criterion [1] as a whole, we surely would be justified in branding it both haphazard and internally incoherent.

\title{
III. The Cause of the Court's Doctrinal Incoherence
}

Both the Spence test and the Clark test represent failures of judicial craftsmanship of truly stunning proportions. With respect to each test the manifest incoherence of the Court's doctrine is matched only by its insensitivity to obviously pertinent First Amendment considerations. One could adduce many, many other similar failures, from the dismal jumble of the Court's public forum doctrine ${ }^{103}$ to the shrill inconsistency of its commercial speech doctrine. ${ }^{104}$ In fact I would go so far as to say that the Court's First Amendment jurisprudence, which is a lively and growing area of constitutional law, dances now macabrely on the edge of complete doctrinal disintegration.

What is the cause of this unhappy situation? It is not, I think, that our contemporary Court is unusually incompetent or unequal to the task of developing solid judicial doctrine. On the whole the Court strikes me as reasonably able and professional, certainly qualified to do what Thomas Kuhn would call

101. 113 S. Ct. 1505 (1993).

102. Id. at 1516-17. For examples outside the context of criterion [1] of the Court using a facial analysis to assess the content neutrality of regulations, see McIntyre v. Ohio Elections Commission, 115 S. Ct. 1511, 1518 (1995); Burson v. Freeman, 504 U.S. 191, 197 (1992) (Blackmun, J., plurality opinion).

103. Robert Post, Between Governance and Management: The History and Theory of the Public Forum, 34 UCLA L. Rev. 1713 (1987); see also David J. Goldstone, The Public Forum Doctrine in the Age of the Information Superhighway (Where are the Public Forums on the Information Superhighway?), 46 Hastings L.J. 335, 369 (1995).

104. Compare Edenfield v. Fane, 113 S. Ct. 1792 (1993) (striking down a Florida ban on inperson solicitation by certified public accountants) with United States v. Edge Broadcasting Co., $113 \mathrm{~S}$. Ct. 2696 (1993) (upholding federal statutes prohibiting radio broadcast of advertisements for lotteries in neighboring states by broadcasters located and licensed in non-lottery states). 
"normal science." I would suggest that the difficulty is rather that the Court's normal science leads it repeatedly to doctrinal disaster. The Court is working within a paradigm of First Amendment jurisprudence that is fundamentally misguided, because it persistently presses the Court to formulate doctrinal standards that frame incoherent and unanswerable questions.

Doctrine is a tool that directs judicial attention to issues deemed relevant to the legal resolution of a case. Doctrine therefore always presupposes a picture of how the world may be categorized so as to be rendered amenable to legal judgment. Contemporary First Amendment doctrine displays an image of the world in which something that can be called "speech" is made salient as a generic object of First Amendment protection. The origins of this orientation no doubt lie in the text of the First Amendment itself, which refers generally to "the freedom of speech." But speech can be a generic object of constitutional protection only if there is present in speech a generic constitutional value. This point is aptly captured in Frederick Schauer's famous notion of a "free speech principle," which aspires to explain why courts should constitutionally demand of the state "a stronger justification ... for limitations of speech than for limitations of other forms of conduct."10s

Schauer was one of the first to attempt to comprehensively catalogue and evaluate each of the several distinct plausible candidates for a free speech principle. ${ }^{106}$ His work has been enormously influential, for it is now common for First Amendment scholarship to articulate a more or less standard list of such candidates to be used to measure the desirability of proposed solutions to First Amendment problems. ${ }^{107}$ But, as anyone who is familiar with this literature knows, it is also common for readers of First Amendment scholarship to skip these exercises in assessment because of their formulaic, abstract, and generally unhelpful nature. The reason for this is readily discernible in Schauer's own work: There is in fact no general free speech principle, as Schauer verges on acknowledging.

The standard list of candidates for a free speech principle ranges from the pursuit of truth to democratic self-governance. Each of these values seems pressing when applied to speech in some situations, but not when applied to speech in other situations. We might agree, for example, that speech within universities serves the value of the pursuit of truth because it establishes an effective marketplace of ideas, and we might construe the doctrine of academic freedom as designed to recognize and protect this value. But it is equally plausible, and not at all inconsistent, to conclude that this value is not very important with respect to certain kinds of speech between doctors and their patients, because patients depend upon, and ought to be able to rely upon, the advice of their doctors. We might construe our practice of subjecting doctors to liability for malpractice for rendering false opinions as evidence of this conclusion.

105. Frederick Schauer, Free Speech: A Philosophical Engutry 8 (1982).

106. For an important precursor of Schauer, see Thomas I. EMERSON, THE SySTEM OF FreEdom OF EXPRESSION 6-7 (1970).

107. See Williams, supra note 4 , at $676-96$, for a fine up-to-date version of this list. 
Or, to pick another example, we might agree that statements about matters of public concern serve the value of democratic self-determination, and we might construe the First Amendment immunity afforded these statements from many forms of common law liability as reflecting the importance we attribute to this value. But it is also plausible, and not at all inconsistent, to conclude that the value of democratic self-governance is not particularly important with respect to many forms of speech about matters of merely private concern, and we might interpret the continuing regulation of such speech by common law torts as reflecting this conclusion. 108

The reason why each of these various values seems paramount only with respect to particular circumstances is that such values represent virtues implicit in specific and discrete kinds of social practices. Democracy is not merely a matter of talking; it also involves all the complicated forms of social interaction by which we govern ourselves. Truth-seeking is not merely a matter of sentences and propositions; it also involves habits of mind, priorities of reason, intersubjective orientations, and attitudes that, when taken together, make up what we recognize to be rational exchange or a collective search for knowledge. Speech is of course prerequisite for both democracy and truth-seeking, but speech alone, in the absence of other necessary social practices, will not yield the values we seek in either democracy or truth-seeking.

The most general statement of this point is that all legal values are rooted in the experiences associated with local and specific kinds of social practices. Because law is ultimately a form of governance, it does not deal with values as merely abstract ideas or principles. Values in the law function instead to signify concrete forms of actual or potential social life in which what we consider desirable may find its realization. This is also true of the constitutional values to which we appeal for the protection of speech. These values find their embodiment in particular forms of social interaction, rather than in speech per se. That is why the search for any general free speech principle is bound to fail. Were the Constitution to recognize and impose a single general value for speech, it would in a Procrustean way force the entire spectrum of state regulation of forms of social interaction into conformity with the particular social practices required by that single value. But our social life is simply too diverse and rich to be compressed into any such single pattern. All of life is not about truth-seeking; nor is it about democracy. It would be neither plausible nor desirable to make it so.

It is of course true that speech is special, for speech uniquely serves as the precondition to the very existence of social institutions and practices. Social life could not regularly and recognizably proceed in the absence of speech. This fact may partially motivate the effort to attribute to speech a single overriding constitutional value. The candidate for a free speech principle that most closely captures this notion of universality is that known variously as "individ-

108. See, e.g., Contreras v. Crown Zellerbach Corp., 565 P.2d 1173 (Wash. 1977) (holding that definition of tort of outrage encompasses Mexican-American man's allegation that former employer subjected him to verbal ridicule). 
ual self-realization,"109 "individual self-fulfillment,"110 or "human liberty."111 Since the potential "to use speech to develop [oneself] or to influence or interact with others in a manner that corresponds to [one's] values"112 is everywhere and always present, it might be thought that this justification for First Amendment protection would indeed be universal.

But any such conclusion would overlook the fact that from the perspective of the legal system self-realization is itself a social, not merely a private, practice, ${ }^{113}$ and that like any social practice it has its appropriate time and place. No sane legal system would view the practice of medicine as an occasion for physician self-realization, at least to the extent that such self-fulfillment diverges from accepted standards of safe and sound medicine. The behavior and therefore the speech of doctors is thus regulated so as to uphold these standards, whether or not such regulation impinges on human liberty. Similarly we do not permit lawyers, parties, and judges in a courtroom to use speech merely as a means of self-development, but rather we regulate their speech so as to serve the different purpose of achieving fair, just, and expeditious processes of adjudication. ${ }^{114}$ We might say that the practice of adjudication preempts the practice of self-realization and subordinates the latter as a constitutional ground. Or, to adduce another example, the workplace is ordinarily regarded as a site of production rather than self-fulfillment, and speech there is justifiably restricted accordingly. ${ }^{115}$

The most general objection to any single free speech principle is that speech makes possible a world of complex and diverse social practices precisely because it becomes integrated into and constitutive of these different practices; it therefore assumes the diverse constitutional values of these distinct practices. For this reason the capacity of speech to sustain the fabric of all social life leaves no palpable constitutional residue. This line of analysis, if followed to its end, leads to a rather radical conclusion: Speech does not itself have a general constitutional value, but rather we attribute to speech the constitutional values allocated to the discrete forms of social practice that speech makes possible. The unit of First Amendment analysis, in other words, ought not to be speech, but rather particular forms of social structure. ${ }^{116}$

Acceptance of this conclusion would remove us from the dominant First Amendment paradigm that informs the Court's contemporary doctrine. The premise of that paradigm is that speech should be accorded generic constitutional value. The Spence test offers a particularly clear doctrinal expression of

109. Martin H. Redish, The Value of Free Speech, 130 U. PA. L. Rev. 591,593 (1982).

110. EMERSON, supra note 106, at 6.

111. C. Edwin Baker, Human Liberty and Freedom of Speech (1989).

112. Id. at 59.

113. See id. at 119-20. On the larger social context of this practice, see 2 C. TAYzor, Atomism, in Philosophy and the Human Sciences: PhILosophical Papers 205-09 (1985).

114. See Robert C. Post, The Management of Speech: Discretion and Rights, 1984 SuP. Cr. REv. $169,193-206$.

115. See Connick v. Myers, 461 U.S. 138, 147 (1983).

116. Robert C. Post, Constitumonal Domans: Democracy, Communtty, Management 120 (1995). 
this premise. Spence attempts to locate the essence of speech, and hence of the constitutional value of speech, in discrete acts of communication that are independent from any social context. Spence attributes an independent constitutional value to speech per se because it imagines speech as subsisting in some abstract world uncontaminated by concrete social practices. But there is no such world; speech is always situated in real social space. Indeed, as a practical matter, we daily confront situations in which communicative acts are embedded within social practices that do not carry any constitutional value. Navigation charts for aircraft do not constitutionally register as speech because we perceive them as imbued with the same constitutional value as any other goods for sale in the marketplace. The aspiration to make speech itself the basic unit of First Amendment analysis thus leads Spence directly to doctrinal incoherence.

Some of the implications of the conceptual shift I am suggesting can perhaps be illustrated by reference to the relatively familiar, narrow, and welldefined social systems represented by organizations. ${ }^{117}$ As Talcott Parsons has observed, "the defining characteristic of an organization which distinguishes it from other types of social systems" is its "primacy of orientation to the attainment of a specific goal." 118 From a constitutional point of view, the value of an organization is the value of its objective. To achieve its objective, an organization must manage the resources within its control. These resources include institutional personnel and, a fortiori, the speech of these personnel.

For this reason the military must regulate the speech of soldiers so as to attain the end of national defense; courts must manage the speech of litigants and witnesses so as to further the goals of justice; schools must manage the speech of students so as to accomplish the objective of education; and so forth. The Supreme Court has accommodated itself to this necessity by facilitating the routine instrumental regulation of speech within government organizations. Such regulation is incompatible with what would ordinarily be regarded as permissible restrictions on speech outside of organizations.

Of course the question of when speech ought to be legally categorized as "within" a government organization itself entails a positive and creative feat of constitutional interpretation. If, for example, an army private writes a letter to his Senator, a court could view the letter as part either of the organization of the military or of the social practice of democratic self-government. The letter will carry different constitutional value, and will consequently be protected according to different doctrinal rules, depending on its characterization. Something like this conclusion was recognized long ago by Immanuel Kant:

Many affairs which are conducted in the interest of the community require a certain mechanism through which some members of the community must passively conduct themselves with an artificial unanimity, so that the government may direct them to public ends, or at least prevent them from destroying those ends. Here argument is certainly not allowed - one must obey. But so far as a part of the mechanism regards himself at the same time as a member of the

117. The argument and evidence for this illustration are set forth in detail in Post, supra note 103.

118. Talcott Parsons, Suggestions for a Sociological Approach to the Theory of Organizations-I, 1 ADMIN. ScI. Q. 63, 64 (1956). 
whole community or of a society of world citizens ... he certainly can argue without hurting the affairs for which he is in part responsible as a passive member. Thus it would be ruinous for an officer in service to debate about the suitability or utility of a command given to him by his superior; he must obey. But the right to make remarks on errors in the military service and to lay them before the public for judgment cannot equitably be refused him as a scholar. ${ }^{119}$

Categorizing speech as either within or without an organization is part and parcel of the more fundamental judicial task of recognizing, defining, and attributing constitutional values to specific forms of social order, and of grasping the function of speech in the achievement of those constitutional values. We might conceptualize this task as a kind of interpretative charting of the ambient social landscape. Such charting is necessarily creative and dialectical: Values already recognized as constitutional may precipitate the perception of practices deemed prerequisite for their realization, while actual but untheorized practices may spur the explicit articulation of new constitutional values.

I have elsewhere surveyed in some detail the Court's opinions dealing with the regulation of speech within government institutions, ${ }^{120}$ and I have found that the pattern of the Court's decisions is largely what would be predicted by the preceding discussion. What is striking, however, is that the Court has been completely unable to craft a clear and useful doctrinal expression of this analysis. In fact, its doctrine in this area has been notoriously turgid and confused, thoroughly disconnected from the actual levers of its judgment. ${ }^{121}$ The root difficulty, I think, is that the Court has labored within the dominant First Amendment paradigm and hence has fruitlessly struggled to craft a doctrine that would reflect a universal and generic constitutional value for speech. It has thus blinded itself to the particular constitutional values actually carried by speech within state organizations.

The most prominent and important form of social order for First Amendment jurisprudence is what I have elsewhere called "democracy."122 I will not repeat here the arguments I have offered in other places that large patches of core First Amendment doctrine in fact express the normative aspirations of this specific kind of social order, which seeks to sustain the value of self-government by reconciling individual and collective autonomy through the medium of public discourse. Democracy strives to create a structure of governance that will be continuously open to the emergence of "a common will, communicatively shaped and discursively clarified in the political public sphere."123

119. IMMANUEL KANT, What is Enlightenment?, in Foundations of The METAPHYSICS of Morals 85, 87 (Lewis White Beck trans., 1959).

120. Post, supra note 103.

121. See id. at 1716 n.7.

122. See, e.g., Robert C. Post, Between Democracy and Community: The Legal Constitution of Social Form, in Democratic Community: NOMOS XXXV 163-90 (John W. Chapman \& Ian Shapiro eds. 1993) [hereinafter Democratic Communty]; Robert C. Post, Racist Speech, Democracy, and the First Amendment, 32 WM. \& MARY L. REv. 267 (1990) [hereinafter Racist Speech]; Robert C. Post, The Constitutional Concept of Public Discourse: Outrageous Opinion, Democratic Deliberation, and Hustler Magazine v. Falwell, 103 HARv. L. REv. 601, 631 (1990) [hereinafter Constitutional Concept].

123. 2 Jürgen Habermas, The Theory of Communicattve Action 81 (Thomas McCarthy trans., 1987). 
Such a structure has both normative and material dimensions. An important normative dimension is the principle that public discourse should not be censored in the name of any fixed or antecedent concept of national identity, because such censorship would impose a determinate vision of the common will and hence foreclose processes of collective self-determination that ought to be perennially open to revision. ${ }^{124}$ One uniquely American doctrinal expression of this normative dimension is the rule "that in public debate our own citizens must tolerate insulting, and even outrageous, speech in order to provide 'adequate "breathing space" to the freedoms protected by the First Amendment." "125 This rule essentially immunizes public discourse from the legal imposition of community norms of decency and respect. ${ }^{126}$

An important material dimension of public discourse is that there be a wide circulation of "similar social stimuli."127 This circulation creates a public communicative sphere by making common experiences available to those who would otherwise remain unconnected strangers. ${ }^{128}$ The means of communicative exchange, whereby "a common will" can forge itself through interactions that I have previously described as roughly dialogic, ${ }^{129}$ make up another important material dimension of public discourse. These prerequisites for democracy are commonly met in modern industrial societies by what the Court has doctrinally labeled media for the communication of ideas. These media combine to form a structural skeleton that is necessary, although not sufficient, for public discourse to serve the constitutional value of democracy.

The two dimensions of Table I are roughly keyed to these material and normative prerequisites for public discourse. Table I suggests that First Amendment scrutiny should be triggered either when the state attempts to regulate media for the communication of ideas, which is to say when the state tampers with the material bases of public discourse, or when the state attempts to act for reasons that are inconsistent with the normative justifications for public discourse. We can thus read Table I as an effort to clarify the particular ways in which speech advances the constitutional values of democracy. For this reason Table I would be quite out of place when applied to other social domains; it would, for example, be useless within the field of government organizations, where the very concept of a medium for the communication of ideas would seem wholly out of place. That is why I noted earlier that Table I has only a limited range of application.

But this limitation is itself suggestive of how doctrine ought to function under the alternative paradigm of First Amendment jurisprudence that I propose. Instead of aspiring to articulate abstract characteristics of speech, doc-

124. See Robert Post, Meiklejohn's Mistake: Individual Autonomy and the Reform of Public Discourse, 64 U. Colo. L. Rev. 1109, 1116-19 (1993).

125. Boos v. Barry, 485 U.S. 312, 322 (1988) (O'Connor, J., plurality opinion) (quoting Hustler Magazine, Inc. v. Falwell, 485 U.S. 46, 56 (1988)).

126. See Democratic Community, supra note 122, at 173-74. (1952).

127. John W. Bennett \& Melvin M. Tumin, Soclal Life: Structure and Function 140

128. Constitutional Concept, supra note 122, at 635.

129. See text accompanying notes 21-22 supra. 
trine ought to identify discrete forms of social order that are imbued with constitutional value, and it ought to clarify and safeguard the ways in which speech facilitates that constitutional value. The Court's failure to use doctrine in this way is one important cause of the collapse of the Clark test for legitimate time, place, and manner regulations.

Although announced in universal terms, the Clark test is in fact meant to apply primarily to public discourse. It is only within the context of public discourse that the norm of content neutrality makes sense. In most forms of social practice content neutrality is not a constitutional value. In organizations, for example, content and even viewpoint discrimination must necessarily occur on a routine basis. It would be perfectly appropriate for the President to fire a cabinet official for expressing public disagreements with administration policy, or for an army general to sanction a subordinate officer for expressing inappropriate opinions about civilian control over the military. ${ }^{130}$

If we understand the Clark test as meant to guide substantive First Amendment decisions about the constitutionality of restrictions on speech within public discourse, its deficiencies are immediate and glaring. The test permits restrictions on speech without any comprehensive assessment of their impact on media for the communication of ideas. This is scarcely plausible as doctrine, and, as Ladue indicates, ${ }^{131}$ even the Court will not follow it in actual cases. But this doctrinal failure is explicable on the supposition that the Court, impelled by the dominant First Amendment paradigm to fashion a generic doctrinal test to protect speech as such, never thought to focus on the particular ways that speech makes possible the material preconditions of the specific social order of democracy.

The Court's decisions interpreting criterion [1] of the Clark test are subject to a similar diagnosis. The decisions reading criterion [1] as prohibiting discrimination simply overlook the fact that virtually every governmental action affects public discourse. ${ }^{132}$ This means that the concept of discrimination, by itself, cannot be doctrinally useful, for what ought to count as "discrimination" can be determined only by reference to some normative theory of public discourse. So, for example, the President of the United States may speak to the nation in an effort to sway public opinion in favor of a program of public health care, and he may therefore have both the purpose and effect of "discriminating" against certain ideas within public discourse. But surely this does not pose a First Amendment problem. Criterion [1] is thus incapable of meaningful elaboration so long as it is interpreted to address the abstract issue of discrimination against speech; it must instead be interpreted to address the particular normative requirements of public discourse and democracy.

Analogous difficulties surface in the Court's decisions interpreting criterion [1] according to secondary effects doctrine. The Court has conceived the doc-

130. For a full discussion, see Post, supra note 103, at 1824-32.

131. See text accompanying notes 69-74 supra.

132. See generally Larry A. Alexander, Trouble on Track Two: Incidental Regulations of Speech and Free Speech Theory, 44 HAstrngs L.J. 921 (1993) (noting distributional effects of government action in speech). 
trine as an effort to express general truths about the generic relationship between speech and causality. But because there are no such truths, the doctrine has inevitably remained confused and undeveloped. To the extent that the Court's actual decisions have expressed a consensus about the distinction between secondary and primary effects, they have refiected well-established understandings of the specific normative nature of public discourse. In fact, the doctrine has conflated at least two distinct normative principles of public discourse.

The first principle is present in those cases in which the Court has used the doctrine to trigger strict scrutiny for regulations that attempt to restrict speech because of the harms that information conveyed by speech might cause. In such cases the Court has refused to adopt a "highly paternalistic approach" and has instead insisted on the "assum[ption] that ... information is not in itself harmful, that people will perceive their own best interests if only they are well enough informed, and that the best means to that end is to open the channels of communication rather than to close them."133 This assumption expresses the normative premise that participants in public discourse are to be regarded as autonomous. ${ }^{134}$ This premise is largely ascriptive, and it is plainly inapplicable in many situations. Indeed the legally established boundaries of public discourse "mark the point at which our commitments shift" from values like autonomous self-determination to competing values like "the dignity of the socially situated self" or the attainment of managerial efficiency. ${ }^{135}$ The nature of the legal subject is regarded quite differently in these other domains. ${ }^{136}$

A second and distinct principle is visible in those cases in which the Court has used secondary effects doctrine to trigger strict scrutiny for regulations that attempt to restrict speech on the grounds of its "offensiveness." This use of the doctrine insulates public discourse from the control of community norms and thereby guarantees that democracy will be independent from community. ${ }^{137}$ The belief that public discourse ought to be immunized from the imposition of community norms represents a very different principle from the belief that participants in public discourse ought to be regarded as autonomous. A healthy doctrine would therefore carefully distinguish between them and would give to each a separate articulation so as to clarify and define its proper scope of application. But instead the Court has collapsed them together into some muddy notion of causality that poses a generic and socially decontextualized issue of the relationship between speech and harm. Off on a quixotic search for the

133. Linmark Assoc., Inc. v. Township of Willingboro, 431 U.S. 85,97 (1977) (quoting Virginia State Pharmacy Bd. v. Virginia Citizens Consumer Council, 425 U.S. 748, 770 (1976)).

134. See, e.g., Thomas Scanlon, A Theory of Freedom of Expression, 1 PHrL. \& PuB. AFr. 204, 215-22 (1972). For a discussion of this presumption of autonomy, see Post, supra note 124, at 1128-33.

135. Constitutional Concept, supra note 122 , at $680,684-85$.

136. Post, supra note 116, at 1-20. Persons in the workplace, for example, are commonly not legally regarded as autonomous, self-constituting subjects. See, e.g., NLRB v. Gissel Packing Co., 395 U.S. 575, 617 (1969) (noting that employees are "economically dependent" on their employers); Post, Racist Speech, supra note 122, at 289 . Neither are patients of doctors nor users of aviation charts.

137. See Constitutional Concept, supra note 122, at 626-66. 
meaning of such concepts as "listeners' reactions,"138 the Court has once again failed to examine the particular social practices that actually give constitutional significance to its decisions.

\section{CONCLUSION}

If my diagnosis is correct, the Court's doctrinal failures stem from a common cause. The Court has attempted to formulate general principles for the constitutional protection of "speech as such." But "speech as such" has no constitutional value, and so the Court's project has been doomed from the start. Constitutional value inheres instead in specific forms of social order, and, in point of actual judicial practice, speech has tended to receive the constitutional protection necessary for it to facilitate the maintenance and success of specific forms of social order.

I want to distinguish this point from the more usual claim that speech can assume many different values that ought to be "balanced" against each other and against other competing social concerns. ${ }^{139}$ There are of course circumstances when First Amendment decisionmaking entails the exercise of practical judgment that must somehow make sense of numerous disparate and incompatible considerations. The First Amendment may require this kind of practical judgment when media for the communication of ideas are regulated for perfectly appropriate reasons. We can call this "balancing" if we wish, but we ought to be aware that if used indiscriminately the metaphor can have several other quite misleading implications.

First, the metaphor of balancing often evokes an image of weighing the rights of one party against those of another. My right to speak is weighed against your right to an unimpaired reputation, or against the state's right to preserve its national security, or against X's right to be free from sexual harassment. This image, flowing as it does from notions of commutative justice, seems to me fundamentally misguided in the application of First Amendment jurisprudence.

If the analysis I have developed in this paper is accurate, courts decide First Amendment cases by authorizing particular social practices. For this purpose rights ought not to be regarded as the private attachments of persons or entities, but rather as the instruments by which the law locates, defines, and sustains desirable social practices. So, for example, if I am a government employee, judicial definition of my "right" to criticize the government will depend upon whether a court will recognize in the social space of my utterance either the practice of democracy or the social structures of an organization. This is not a matter, as the Court once famously stated in Pickering v. Board of Education, of arriving "at a balance" between my rights and those of a state organiza-

138. See, e.g., Boos v. Barry, 485 U.S. 312, 321 (1988).

139. See, e.g., Steven Shiffrin, Defamatory Non-Media Speech and First Amendment Methodology, 25 UCLA L. REV. 915, 955-58 (1978). 
tion, ${ }^{140}$ but rather of a court deciding what kind of social practice ought to obtain constitutionally in the circumstances of my speech. ${ }^{141}$

A second unfortunate consequence of the metaphor of balancing is its implication that the outcome of First Amendment decisions can generally be understood as a compromise between competing interests. The image is that the law takes a little from column A, and a little from column B, and somehow muddles forward in a manner that accommodates the essential demands of all sides. There are no doubt occasions when the law does just this. But it is frequently the case that in First Amendment adjudication the question for decision is what social practice ought to be legally recognized in a particular context.

In such circumstances the idea of compromise is misplaced, because social practices have an internal logic and coherence. ${ }^{142}$ To adjudicate with self-conscious effectiveness courts must be able to grasp and apply the principles that make up the internal integrity of specific social practices (which I have elsewhere, and perhaps infelicitously, called "formal analysis"143). But even without this awareness, judicial decisions will often in the end reflect one set of principles rather than another, and they will therefore authorize one practice rather than another. In such circumstances judicial decisions can most helpfully be conceptualized as drawing boundaries between distinct social practices. This is quite a different image from that of compromising disparate interests.

Third, and perhaps most important, the image of balancing tends to focus judicial attention on abstract values or interests. Courts see themselves as weighing "truth" against "reputation," or "democracy" against "privacy." The values are envisioned as so many balls juggled in the air. But this is a very distorted picture, for the significance of legal values is in fact always inseparably connected to the social practices that are the precondition for their actual realization. We can of course reflect on these practices and attempt to change and improve them. But we cannot ever write on a clean slate, as though legal values and interests simply fell disembodied from a clear sky. To view First Amendment questions in terms of the boundaries of practices, therefore, has the significant benefit of forcing courts to consider the material and social dimensions of constitutional values.

The implication of this discussion is that First Amendment doctrine can recover its rightful role as an instrument for the clarification and guidance of judicial decisionmaking only if the Court refashions its jurisprudence so as to foster a lucid comprehension of the constitutional values implicit in discrete forms of social order. The Court must reshape its doctrine so as to generate a

140. 391 U.S. 563, 568 (1968). For a recent reiteration of the metaphor, see United States v. National Treasury Employees Union, 115 S. Ct. 1003, 1012 (1995).

141. It is of course true that in deciding this question a court may have to review and assimilate many disparate and incommensurate considerations. For a good discussion of this point, see Richard $\mathrm{H}$. Pildes, Avoiding Balancing: The Role of Exclusionary Reasons in Constitutional Law, 45 HAstings L.J. 711 (1994).

142. For an argument to this effect, see Post, supra note 116, at 1-20.

143. Racist Speech, supra note 122, at 325-27. See Frank Michelman, Universities, Racist Speech and Democracy in America: An Essay for the ACLU, 27 HARV. C.R.-C.L. L. REv. 339, 345-47 (1992). 
perspicuous understanding of the necessary material and normative dimensions of these forms of social order and of the relationship of speech to these values and dimensions. The Court must also develop doctrinal means for allocating speech to these distinct forms of social orders.

This is, I realize, rather abstract advice. It certainly will not assist the Court in settling any particular controversy. But it will direct the Court toward the right questions, by which I mean those questions whose case by case development will enable the emergence of a successful and useful First Amendment doctrine. ${ }^{144}$ In so complicated and contextual an area as the First Amendment, it may be that the most we can ask of doctrine is that it focus attention on inquiries that elucidate the actual levers of decision.

144. I have elsewhere attempted to demonstrate just how very useful these questions are. See generally Post, supra note 116. 
HeinOnline -- 47 Stan. L. Rev. 1282 1994-1995 